\title{
Proteomics study of the antifibrotic effects of a-mangostin in a rat model of renal fibrosis
}

\author{
Thana Chaeyklinthes' ${ }^{1}$, Vilailak Tiyao² ${ }^{2}$ Sittiruk Roytrakul ${ }^{3}$, Narumon Phaonakrop ${ }^{3}$, \\ Udomsri Showpittapornchai ${ }^{2}$, Wisuit Pradidarcheep ${ }^{2, *}$
}

Abstract

Background: Renal fibrosis is a consequence of a "faulty" wound-healing mechanism that results in the accumulation of extracellular matrix, which could lead to the impairment of renal functions. $\alpha$-Mangostin (AM) may prevent the formation of liver fibrosis, but there has yet to be a conclusive investigation of its effect on renal fibrosis.

Objectives: To investigate the renoprotective effect of AM against thioacetamide (TAA)-induced renal fibrosis in rats at the morphological and proteomic levels.

Methods: We divided 18 male Wistar rats into 3 groups: a control group, a TAA-treated group, and a TAA + AM group. The various agents used to treat the rats were administered intraperitoneally over 8 weeks. Subsequently, the morphology of renal tissue was analyzed by histology using Sirius Red staining and the relative amount of stained collagen fibers quantified using ImageJ analysis. One-dimensional gel liquid chromatography with tandem mass spectrometry (GeLC-MS/MS) was used to track levels of protein expression. Proteomic bioinformatics tools including STITCH were used to correlate the levels of markers known to be involved in fibrosis with Sirius Red-stained collagen scoring.

Results: Histology revealed that AM could reduce the relative amount of collagen fibers significantly compared with the TAA group. Proteomic analysis revealed the levels of 4 proteins were modulated by AM, namely CASP8 and FADD-like apoptosis regulator (Cflar), Ragulator complex protein LAMTOR3 (Lamtor3), mitogen-activated protein kinase kinase kinase 14 (Map3k14), and C-Jun-amino-terminal kinase-interacting protein 3 (Mapk8ip3).

Conclusion: AM can attenuate renal fibrosis by the suppression of pathways involving Cflar, Lamtor3, Map3k14, and Mapk8ip3.

Keywords: fibrosis; kidney diseases; alpha-mangostin; proteomics; xanthones

Renal fibrosis, grim yet elusive, is the evitable consequence of an excessive accumulation of extracellular matrices that manifests itself in all types of chronic kidney disease (CKD). The term "grim" is not used lightly and is founded upon the profound burden carried by those affected with CKD [1]. According to Turin et al., for a person aged 40 years with an estimated glomerular filtration rate (eGFR) of 15-29 mL/ $\min / 1.73 \mathrm{~m}^{2}$, eGFR that can be interpreted as a severe decrease in renal function from a normal expected eGFR of $\geq 90 \mathrm{~mL} / \mathrm{min} / 1.73 \mathrm{~m}^{2}$, and would have a life expectancy of 9.1-10.4 years [2]. Elusive - a term we have carefully selected to highlight the nature of $\mathrm{CKD}$ - is also founded upon strong

*Correspondence to: Wisuit Pradidarcheep, Department of Anatomy, Faculty of Medicine, Srinakharinwirot University, Bangkok 10110, Thailand, e-mail: wisuit@g.swu.ac.th

'Department of Science, Mahidol University International College, Mahidol University, Nakhon Pathom 73170, Thailand 2Department of Anatomy, Faculty of Medicine, Srinakharinwirot University, Bangkok 10110, Thailand ${ }^{3}$ National Center for Genetic Engineering and Biotechnology, National Science and Technology Development Agency, Pathum Thani 12120, Thailand ¿ Open Access. (c) 2018 Thana Chaeyklinthes et al., published by Sciendo. (c) BY-Nc-ND This work is licensed under the Creative Commons Attribution NonCommercial-NoDerivatives 4.0 License. 
evidence. A state of renal fibrosis is an evitable consequence of the gradual accumulation of extracellular matrices, this monotonous "accumulation" is a by-product of faulty tissue restoration and healing processes when they have sustained repeated damage from various sources [3]. Examples of such sources or risk factors are certain drugs such as those belonging to large classes of antibiotics including aminoglycosides, $\beta$-lactams, vancomycins, sulfonamides, or specific drugs such as acyclovir and amphotericin-B [4]. Preexisting health conditions such as cardiovascular diseases, diabetes mellitus, and certain metabolic syndromes can also serve to initiate renal fibrosis [5]. Other confounding factors include genetics, ethnicity, socioeconomic status, age, and sex [6]. If left unaddressed, the ultimate fate of such accumulation is gradual organ deterioration capable of descending into an irreversible and debilitating state of end-stage renal disease (ESRD).

The current prospects for patients with ESDR are grim, i.e., to undergo hemodialysis or organ transplant as there have yet to be any drugs in clinical use that specifically target kidney cells or kidney fibrosis [7]. However, because the fibrotic state is able to be reversed and tissue rejuvenated, researchers have developed a keen interest toward revealing the precise mechanisms and key mediators that play a variety of different and complicated roles in the progression of renal fibrosis in to attempt to develop effective antifibrotic drugs [8]. In the light of such revelations and developments, advancement in modern scientific methods has allowed investigation of traditional remedies known to harbor a myriad of benefits. One such traditional remedy is an extract from the pericarp of the fruit of Garcinia mangostana Linn, commonly known as mangosteen.

G. mangostana is indigenous to Asian regions such as Malaysia, Myanmar, Thailand, the Philippines, Sri Lanka, and India. The pericarp of the fruit is considered to possess a wide range of actions including antioxidant, anticancer, antiinflammatory, antiallergy, analgesic, antimicrobial, antiparasitic, and antiobesity properties [9]. Central to these properties is a secondary xanthone metabolite known as $\alpha$-mangostin (AM) [10]. Studies we conducted in vivo found that treatment with AM could reduce thioacetamide (TAA)-induced hepatic fibrosis [11]. Another study suggested that AM could attenuate lipid peroxidation, reduce proinflammatory mediators, inhibit the activities of hepatic stellate cells, and reduce portal blood pressure in rat models of fibrosis [12]. However, to our knowledge, no proteomic investigation of the effects of AM on renal fibrosis have been reported.

An investigation of whether AM can attenuate renal fibrosis and aid in processes of protection against and reversal of tissue damage, and the mechanisms of AM action in any such attenuation is warranted. To determine whether AM can disrupt progression of renal fibrosis in a rat model of the disease, histopathology using Sirius Red collagen fiber staining, which allows us to determine the relative amount of collagen fibers in renal tissue, and proteomic analysis of protein marker expression was used to understand better potential mechanisms of AM action [13]. One-dimensional gel liquid chromatography with tandem mass spectrometry (GeLC-MS/ MS) was employed to investigate the differential expression of proteins and create a proteomic profile of the effects of AM administration in rats with TAA-induced fibrosis.

\section{Materials and methods}

\section{Experimental animals and sample retrieval}

All procedures involving animals were approved by the Animal Ethics Committee of the Faculty of Medicine, Srinakharinwirot University (Protocol No. U1-01229-2558) and conducted in compliance with The Animals for Scientific Purposes Act, BE 2558 (AD 2015) (Thai Government Gazette, Vol. 132, Part 18 a, 13th March 2015) under a license to use animals for scientific purposes from the Institute of Animals for Scientific Purpose Development (IAD) National Research Council of Thailand following the revised Institute of Laboratory Animal Resources, Commission on Life Sciences, National Research Council "Guide for the Care and Use of Laboratory Animals" Washington, D.C.: National Academy Press; 1996. Male Wistar rats $(\mathrm{n}=18$, range 180-210 g, 5-8 weeks old) were obtained from the National Laboratory Animal Center, Mahidol University, Thailand. The rats were maintained in an air-conditioned animal facility at $22-25^{\circ} \mathrm{C}$ under a 12-h light and dark cycle and allowed food and water ad libitum. We obtained 96\% pure AM (by high-performance liquid chromatography [HPLC] assay) from Associate Professor Primchanien Mongkarndi, Faculty of Pharmacy, Mahidol University, Thailand [14].

The rats were divided without selection into 3 groups of 6 as follows:

Group I: Vehicle control group. Rats in this group were administered $0.8 \mathrm{~mL} / \mathrm{kg}$ of dimethyl sulfoxide (DMSO) mixed with phosphate-buffered saline (PBS) by intraperitoneal injection twice a week for 8 weeks.

Group II: TAA-treated group (TAA group). Rats in this group were given $200 \mathrm{mg} / \mathrm{kg}$ of TAA dissolved in sterile water 3 times a week via intraperitoneal injection for 8 weeks.

Group III: TAA + AM group. Rats in this group were given $200 \mathrm{mg} / \mathrm{kg}$ of TAA as for rats in group II, but were also administered $5 \mathrm{mg} / \mathrm{kg}$ of AM dissolved in $0.8 \mathrm{~mL} / \mathrm{kg}$ of DMSO mixed with PBS twice a week for 8 weeks. 
Rats were killed humanely using an overdose of pentobarbital (Nembutal) anesthesia 8 weeks after the first treatment, and kidneys were collected. One kidney from each rat was fixed in $4 \%$ paraformaldehyde at $4^{\circ} \mathrm{C}$ for histology, and the second kidney was stored at $-80^{\circ} \mathrm{C}$ for proteomic analysis.

\section{Histopathology}

After fixing the kidney tissues with 4\% paraformaldehyde, the tissues were dehydrated in an ascending graded series of ethanol and embedded in paraffin. The tissue blocks were sectioned at 5-7 $\mu \mathrm{m}$ before staining with Sirius Red to assess fibrosis [15]. ImageJ software (http://imagej.nih.gov/ij/docs/ index.html) version $1.51 \mathrm{r}$, was used to quantify the relative area of stained collagen fibers [16]. The area quantified contained at least one glomerulus surrounded by renal tubules of the renal cortex; 20 images were captured per group of rats. The quantification comprised 4 main steps repeated for all images from each group: (1) setting an appropriate scale to ensure correct calculation of area; (2) conversion of the stained image to gray scale; (3) isolation of Sirius Red-stained collagen using thresholding; (4) measuring the thresholded area [16]. The relative fibrotic areas were assessed using a one-way analysis of variance (ANOVA) to determine whether the group means differed significantly $(P<0.01)$ followed by Tukey's multiple comparison test to compare the differences between each pair of means.

\section{Protein extraction, SDS-PAGE, and in-gel digestion}

The kidneys from each group were pooled before proteomic analysis. After homogenizing the tissue in liquid nitrogen and dissolving the homogenate in $0.5 \%$ sodium dodecyl sulfate (SDS), the proteins were precipitated with acetone at $-20^{\circ} \mathrm{C}$. The precipitate was centrifuged at $12000 \mathrm{rpm}(11700 \times \mathrm{g})$ for $15 \mathrm{~min}$, and the pellets resuspended in $0.5 \%$ SDS. The solutions were then sonicated in an ultrasonic bath and centrifuged at $5000 \mathrm{rpm}(2000 \times g)$ for $5 \mathrm{~min}$ to collect the supernatants. The concentration of proteins was determined using a Lowry assay at $690 \mathrm{~nm}$ [17].

The proteins were then separated by SDS-polyacrylamide gel electrophoresis (PAGE; $12.5 \% \mathrm{w} / \mathrm{v}$ ) at $50 \mathrm{~V}$ for the stacking gel and $70 \mathrm{~V}$ once the proteins had entered the separating gel, for a total of $4 \mathrm{~h}$. The height of the separating gel is $8 \mathrm{~cm}$ from the lower glass border on an Atto AE-6540 apparatus (Japan). The separated proteins were silver stained to visualize the bands [18]. The lane for each group was excised from the gel and separated into 15 smaller pieces (from top to bottom of the lane) that were placed into individual wells of a microtiter plate to digest the proteins in-gel.

Each piece of gel was washed twice with $200 \mu \mathrm{L}$ of distilled water for 10 min each time, and the solution was then discarded. The washed gel pieces were then soaked in $200 \mu \mathrm{L}$ acetonitrile for $5 \mathrm{~min}$. After removing acetonitrile, the gel pieces were soaked in $30 \mu \mathrm{L}$ of $10 \mathrm{mM}$ dithiothreitol (DTT) for $1 \mathrm{~h}$ and then incubated in the dark with $100 \mathrm{mM}$ iodoacetamide for $1 \mathrm{~h}$. The solution of DTT and iodoacetamide was then discarded. We then added $10 \mu \mathrm{L}$ of sequencing grade modified trypsin (10 ng/ $\mu \mathrm{L}$ ) (Promega) and $20 \mu \mathrm{L}$ of $30 \%$ acetonitrile and incubated the preparation overnight at $37^{\circ} \mathrm{C}$. The resulting peptide solutions were extracted with $30 \mu \mathrm{L}$ of $50 \%$ acetonitrile $/ 0.1 \%$ formic acid. The extracted peptides were placed into new microtiter plate and incubated at $40^{\circ} \mathrm{C}$ for 1 day. Finally, the samples were dissolved in $15 \mu \mathrm{L} 0.1 \%$ formic acid and examined by liquid chromatography with tandem mass spectrometry (LC-MS/MS) [19].

\section{GeLC-MS/MS and bioinformatics}

The peptides extracted from each piece of gel were injected into an UltiMate 3000 LC System (Dionex) equipped with a reversed-phase nanocolumn and the eluted peptides were detected with an HCTultra PTM Discovery System (Bruker Daltonics). The nanocolumn (PepSwift monolithic column $100 \mu \mathrm{m}$ i.d. $\times 50 \mathrm{~mm}$ ). was eluted with a gradient of eluent $\mathrm{A}$ $(0.1 \%$ formic acid) in eluent B $(80 \%$ acetonitrile in water containing $0.1 \%$ formic acid). Peptides were separated with a linear gradient of from $10 \%$ to $70 \%$ eluent B for $13 \mathrm{~min}$ at $300 \mathrm{~nL} / \mathrm{min}$, including a column regeneration step at $90 \%$ eluent $\mathrm{B}$ and an equilibration step at $10 \%$ eluent B, producing a run time of $20 \mathrm{~min}$. Mass spectra of the peptide fragments were acquired in a data-dependent auto MS/MS mode with a range $300-1500 \mathrm{~m} / \mathrm{z}$ using 3 averages, and up to 5 precursor ions selected from an MS scan $50-3000 \mathrm{~m} / \mathrm{z}$. LC-MS/MS sample injections were automated and made in triplicate.

To quantify proteins, we used DeCyderMS Differential Analysis software (GE Healthcare) [20]. LC-MS/MS raw data were converted, and the PepDetect module was used for automated peptide detection, charge state assignments, and quantification based on the peptide ion signal intensities in MS mode. The analyzed MS/MS data from DeCyderMS were submitted for searching against the National Center for Biotechnology Information (NCBI) database using Mascot software (version 2.3, Matrix Science). Database interrogation was as follows: taxonomy (Rattus norvegicus); enzyme (trypsin); variable modifications (carbamidomethyl, oxidation 


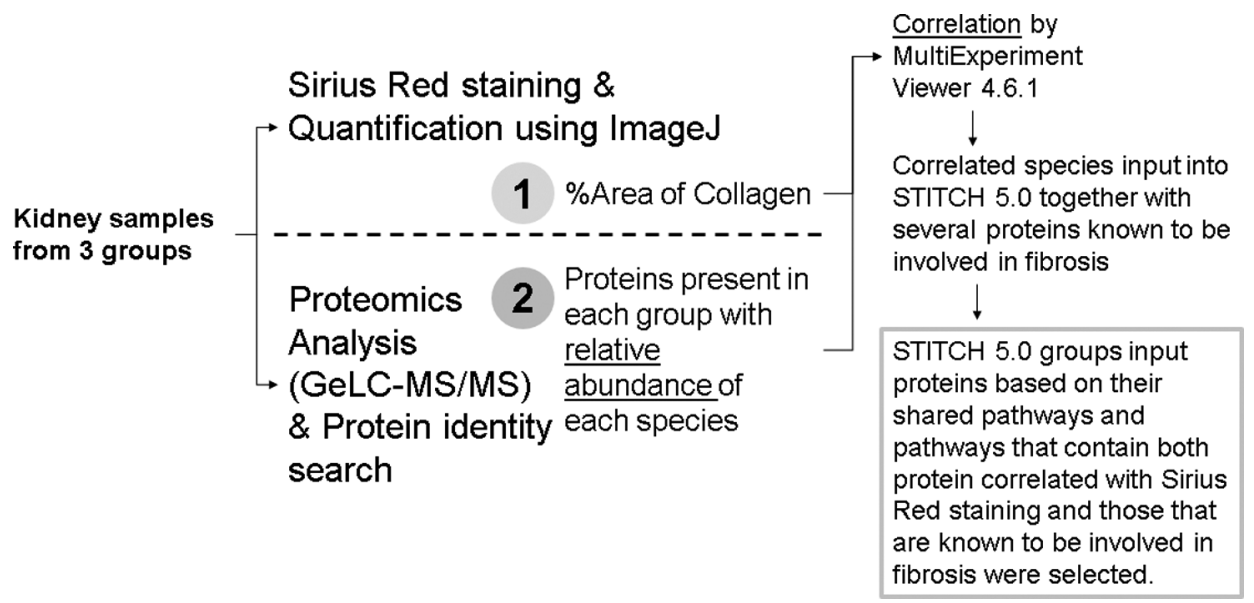

Figure 1. Brief summary of GeLC-MS/MS and bioinformatics methodology. GeLC-MS/MS, gel liquid chromatography-tandem mass spectrometry

of methionine residues); mass values (monoisotopic); protein mass (unrestricted); peptide mass tolerance (1.2 Da); fragment mass tolerance $( \pm 0.6 \mathrm{Da})$, peptide charge state $(1+, 2+$, and $3+$ ), and maximum missed cleavages (3).

Using a self-organizing tree algorithm (SOTA), MultiExperiment Viewer (Mev) software (version 4.6.1) was used to determine the proteins whose level of expression followed the trend of the quantified relative area of collagen fibers. The proteins resulting from the Mev analysis, together with proteins and chemicals that were shown to be involved in fibrosis such as transforming growth factor- $\beta$ (TGF- $\beta$ ), Smads, tissue inhibitors of metalloproteinases (TIMPs), tumor necrosis factor (TNF), folic acid, streptozotocin, and cyclosporine A, were then entered into a Search Tool for Interactions of Chemicals Network (STITCH 5.0; http://stitch.embl.de) to elucidate their cellular functions [21]. Proteins shown to be involved in pathways relevant to the onset of fibrosis, whose information was provided by the Kyoto Encyclopedia of Genes and Genomes (KEGG) pathway analysis available as a part of STITCH 5.0, were reevaluated individually with STITCH 5.0 with a limit of 10 functional partners to elucidate their functions. A flow diagram showing the methodological steps of GeLC-MS/MS and bioinformatics analysis is shown in Figure 1.

\section{Statistical analyses}

The relative fibrotic areas were assessed using a one-way analysis of variance (ANOVA) to determine whether the group means differed significantly $(\mathrm{P}<0.01)$ followed by a Tukey multiple comparison test to compare the differences between each pair of means. The PepMatch module of the DeCyder MS 2.0 differential analysis software allowed for mass spectra with an inadequate match to those on the database to be eliminated $(t$ test and ANOVA, where $P<0.05$ ). Mass spectra were compared across each group using a $t$ test and ANOVA to assess their similarity.

\section{Results}

\section{Histopathology}

Representative graphic output from ImageJ software showing the relative areas of red staining in a given frame across the 3 groups, namely the control group, TAA group, and TAA+AM group, is shown in Figure 2. The accumulation of collagen fibers in Bowman's capsule and the interstitium was significant in the kidneys of rats in which fibrosis was induced by TAA, when compared with the accumulation in the control group $(P<0.001)$. Rats in the TAA + AM group had a reduced area of fibrosis $(P<0.001)$.

\section{GeLC-MS/MS and bioinformatics}

Upon interrogation of the NCBI database with mass spectra from the tandem analysis, we identified 2769 proteins, the majority of which were shared among all 3 groups. The Sirius Red staining (mean relative percentages) as shown in Figure 3 were then employed to compare the scores against the proteomic protein profiles (analyzed using Mev software) across different groups, and 68 proteins belonging to $R$. norvegicus were found to possess similar expression trends to the Sirius Red quantification as summarized in Table 1. These 68 proteins were then analyzed using STITCH 5.0, and 4 of the proteins were found extensively linked to 4 main pathways 


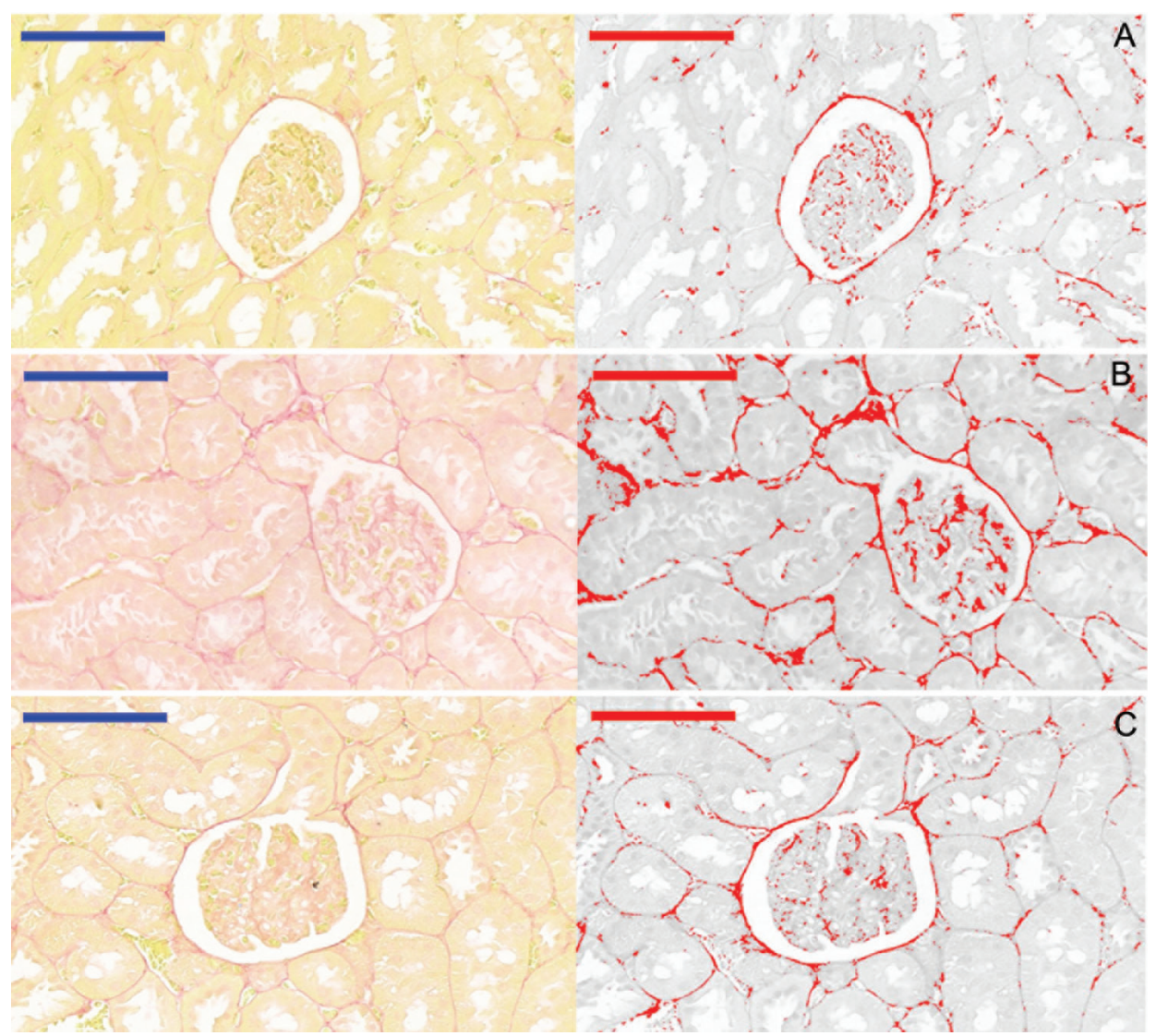

Figure 2. Sirius Red staining of (A) control, (B) TAA, (C) TAA + AM groups and their respective threshold image for the quantification of percent area stained red. AM, a-mangostin; TAA, thioacetamide. Scale bars in blue and red represent $100 \mu \mathrm{m}$

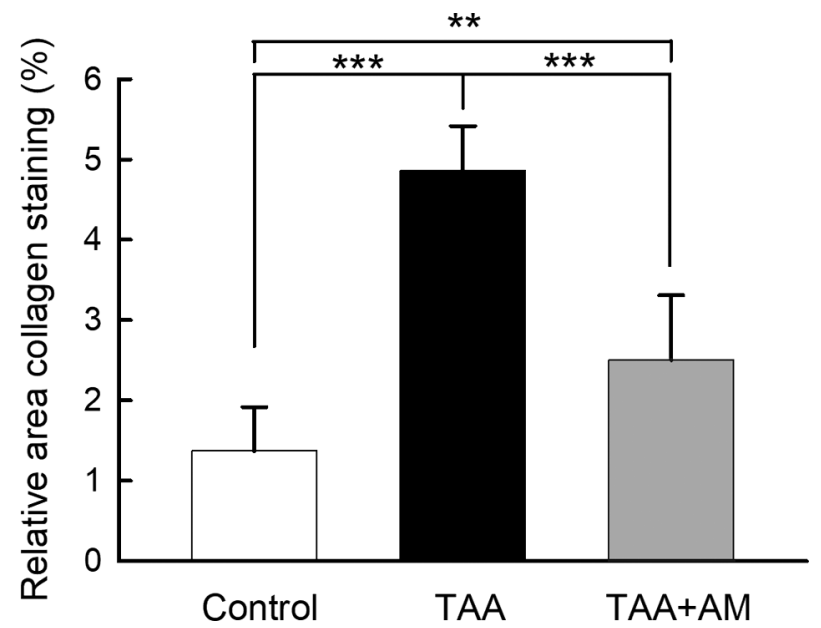

Figure 3. Automated quantification of Sirius Red staining using ImageJ across the 3 experimental groups plotted as relative area (\%) stained red. Bars indicate the means and error bars represent standard deviation (SD). ${ }^{* * *} P<0.001$ when the TAA group (mean $\pm S D$; $4.86 \pm 0.56 \%)$ was compared with the control $(1.37 \pm 0.55 \%)$ and TAA + AM group $(2.50 \pm 0.81 \%) .{ }^{* *} P<0.01(=0.002)$ when the $\mathrm{TAA}+\mathrm{AM}$ group $(2.50 \pm 0.81 \%)$ was compared with the control group AM, a-mangostin; TAA, thioacetamide relevant to fibrosis (as drawn from the KEGG pathway database), namely the apoptotic, TNF-signaling, NF- $\kappa \mathrm{B}$-signaling, and MAPK signaling pathways. The 4 proteins of interest are CASP8 and FADD-like apoptosis regulator (Cflar), Ragulator complex protein LAMTOR3 (Lamtor3), mitogen-activated protein kinase kinase kinase 14 (Map3k14), and C-Jun-aminoterminal kinase-interacting protein 3 (Mapk8ip3), along with the pathways they are involved in as shown in Figures 4-7. The remaining proteins, although shown to have followed the trend of Sirius Red quantification based on Mev software analysis, were discarded due to their nonexistent or weak link to the process of fibrosis as suggested by STITCH 5.0.

\section{Discussion}

Medicinal herb proteomics is a relatively new discipline that applies global protein measurement technologies to probe the effects of medicinal extracts from various natural sources on various diseases. In the present study, properties AM from the pericarp of $G$. mangostana Linn are highlighted. This 
Table 1. Proteins correlated with quantified Sirius Red collagen staining identified by using the self-organizing tree algorithm of Mev software (version 4.6.1). We identified 68 proteins. Accession numbers searchable on NCBI and their identity details are tabulated. $P$-values from $t$ tests are also tabulated to indicate the confidence of identification using Mascot software. The numbers in the column for each group represent the log ion peak intensity for each species.

\begin{tabular}{|c|c|c|c|c|c|}
\hline NCBI accession & Identity details & ${ }^{\dagger} \boldsymbol{P}$ & Control & TAA & TAA+AM \\
\hline NP_036894.2 & Caspase-1 & 7.17E-03 & $1.59 \mathrm{E}+01$ & $1.62 \mathrm{E}+01$ & $1.55 \mathrm{E}+01$ \\
\hline NP_001100608.1 & Protein strawberry notch homolog 1 & 4.09E-04 & $0.00 \mathrm{E}+00$ & $1.74 \mathrm{E}+01$ & $0.00 \mathrm{E}+00$ \\
\hline NP_001005905.1 & T-complex protein 1 subunit beta & $5.40 \mathrm{E}-03$ & $0.00 \mathrm{E}+00$ & $1.75 \mathrm{E}+01$ & $0.00 \mathrm{E}+00$ \\
\hline NP_001020151.1 & Ankyrin repeat domain-containing protein 34A & $3.69 \mathrm{E}-03$ & $1.67 \mathrm{E}+01$ & $1.73 \mathrm{E}+01$ & $1.65 \mathrm{E}+01$ \\
\hline AAB82191.1 & Anti-fluorescein monoclonal lgM heavy chain & $5.22 \mathrm{E}-07$ & $1.59 \mathrm{E}+01$ & $1.67 \mathrm{E}+01$ & $1.49 \mathrm{E}+01$ \\
\hline NP_037081.2 & Beta-enolase & $6.56 \mathrm{E}-03$ & $2.05 \mathrm{E}+01$ & $2.12 \mathrm{E}+01$ & $1.95 \mathrm{E}+01$ \\
\hline NP_113948.1 & Bile salt export pump & $5.84 \mathrm{E}-03$ & $1.91 \mathrm{E}+01$ & $1.96 \mathrm{E}+01$ & $1.76 \mathrm{E}+01$ \\
\hline AAI66492.1 & Bms1 protein & $6.05 \mathrm{E}-03$ & $1.59 \mathrm{E}+01$ & $1.62 \mathrm{E}+01$ & $1.55 \mathrm{E}+01$ \\
\hline NP_058801.1 & Bone morphogenetic protein 3 precursor & $7.67 \mathrm{E}-03$ & $1.95 \mathrm{E}+01$ & $2.16 \mathrm{E}+01$ & $1.86 \mathrm{E}+01$ \\
\hline АAH98803.1 & C1r protein & $8.13 \mathrm{E}-04$ & $1.82 \mathrm{E}+01$ & $1.95 \mathrm{E}+01$ & $1.85 \mathrm{E}+01$ \\
\hline NP_001029036.1 & Cflar isoform $1^{\ddagger}$ & $1.38 \mathrm{E}-06$ & $2.06 \mathrm{E}+01$ & $2.06 \mathrm{E}+01$ & $2.05 \mathrm{E}+01$ \\
\hline NP_001099374.1 & CD209a molecule & $6.01 \mathrm{E}-03$ & $1.34 \mathrm{E}+01$ & $1.61 \mathrm{E}+01$ & $1.43 \mathrm{E}+01$ \\
\hline NP_001102339.1 & Cell death activator CIDE-B & $8.09 \mathrm{E}-03$ & $0.00 \mathrm{E}+00$ & $1.92 \mathrm{E}+01$ & $0.00 \mathrm{E}+00$ \\
\hline NP_001094143.1 & Mapk8ip3 ${ }^{\ddagger}$ & $1.61 \mathrm{E}-04$ & $1.64 \mathrm{E}+01$ & $1.67 \mathrm{E}+01$ & $1.54 \mathrm{E}+01$ \\
\hline AAL86014.1 & Co-activator/regulatory zinc-finger protein NIF & $2.32 \mathrm{E}-03$ & $1.85 \mathrm{E}+01$ & $1.92 \mathrm{E}+01$ & $1.80 \mathrm{E}+01$ \\
\hline NP_690059.1 & Coagulation factor VII precursor & $3.99 \mathrm{E}-03$ & $1.88 \mathrm{E}+01$ & $1.97 \mathrm{E}+01$ & $1.85 \mathrm{E}+01$ \\
\hline NP_001137368.1 & Coiled-coil domain-containing protein 137 & $6.79 \mathrm{E}-04$ & $1.89 \mathrm{E}+01$ & $1.95 \mathrm{E}+01$ & $1.88 \mathrm{E}+01$ \\
\hline NP_001004262.1 & Conserved oligomeric Golgi complex subunit 6 & $7.10 \mathrm{E}-03$ & $1.85 \mathrm{E}+01$ & $1.96 \mathrm{E}+01$ & $1.76 \mathrm{E}+01$ \\
\hline NP_598218.1 & CX3C chemokine receptor 1 & $8.30 \mathrm{E}-03$ & $1.71 \mathrm{E}+01$ & $1.83 \mathrm{E}+01$ & $1.73 \mathrm{E}+01$ \\
\hline NP_001013155.1 & C-X-C motif chemokine 14 precursor & $3.64 \mathrm{E}-03$ & $1.66 \mathrm{E}+01$ & $1.81 \mathrm{E}+01$ & $1.69 \mathrm{E}+01$ \\
\hline NP_001013201.1 & Cytosolic Fe-S cluster assembly factor NARFL & $2.90 \mathrm{E}-03$ & $1.44 \mathrm{E}+01$ & $1.68 \mathrm{E}+01$ & $1.45 \mathrm{E}+01$ \\
\hline NP_001129274.1 & Disks large-associated protein 5 & $8.75 \mathrm{E}-03$ & $1.52 \mathrm{E}+01$ & $1.63 \mathrm{E}+01$ & $1.51 \mathrm{E}+01$ \\
\hline NP_001102999.1 & DNA/RNA-binding protein KIN17 & $7.11 \mathrm{E}-03$ & $1.98 \mathrm{E}+01$ & $2.08 \mathrm{E}+01$ & $1.85 \mathrm{E}+01$ \\
\hline NP_064311.2 & E3 ubiquitin-protein ligase ARIH1 & 5.07E-03 & $1.59 \mathrm{E}+01$ & $1.63 \mathrm{E}+01$ & $1.49 \mathrm{E}+01$ \\
\hline NP_620252.1 & Gamma-aminobutyric acid receptor subunit rho-3 precursor & $2.44 \mathrm{E}-03$ & $1.40 \mathrm{E}+01$ & $1.58 \mathrm{E}+01$ & $1.40 \mathrm{E}+01$ \\
\hline NP_036702.1 & Glutamate dehydrogenase 1, mitochondrial precursor & $4.81 \mathrm{E}-03$ & $1.64 \mathrm{E}+01$ & $1.85 \mathrm{E}+01$ & $1.71 \mathrm{E}+01$ \\
\hline NP_899653.2 & Glutathione peroxidase 2 & $7.58 \mathrm{E}-03$ & $0.00 \mathrm{E}+00$ & $1.64 \mathrm{E}+01$ & $0.00 \mathrm{E}+00$ \\
\hline NP_001007636.2 & GTPase activating protein testicular GAP1 & $3.01 \mathrm{E}-03$ & $1.19 \mathrm{E}+01$ & $1.28 \mathrm{E}+01$ & $1.04 \mathrm{E}+01$ \\
\hline NP_001101888.1 & HEAT repeat-containing protein 1 & $5.38 \mathrm{E}-03$ & $1.82 \mathrm{E}+01$ & $2.04 \mathrm{E}+01$ & $1.84 \mathrm{E}+01$ \\
\hline NP_001099862.1 & Heparan sulfate glucosamine 3-O-sulfotransferase 5 & $3.94 \mathrm{E}-03$ & $1.65 \mathrm{E}+01$ & $1.85 \mathrm{E}+01$ & $1.66 \mathrm{E}+01$ \\
\hline NP_001099302.1 & Homeobox protein DLX-3a & $7.95 \mathrm{E}-04$ & $1.67 \mathrm{E}+01$ & $1.79 \mathrm{E}+01$ & $1.67 \mathrm{E}+01$ \\
\hline NP_001102748.1 & Iron-sulfur cluster assembly 2 homolog, mitochondrial precursor & $1.56 \mathrm{E}-04$ & $1.57 \mathrm{E}+01$ & $1.72 \mathrm{E}+01$ & $1.47 \mathrm{E}+01$ \\
\hline ACX55121.1 & Jarid1d protein & $9.36 \mathrm{E}-03$ & $1.43 \mathrm{E}+01$ & $1.67 \mathrm{E}+01$ & $1.41 \mathrm{E}+01$ \\
\hline NP_001102270.1 & Krueppel-like factor 7 & $6.68 \mathrm{E}-04$ & $1.62 \mathrm{E}+01$ & $1.76 \mathrm{E}+01$ & $1.66 \mathrm{E}+01$ \\
\hline NP_001101180.1 & Leucine-rich repeats and immunoglobulin-like domains protein 2 precursor & $2.94 \mathrm{E}-04$ & $1.87 \mathrm{E}+01$ & $1.93 \mathrm{E}+01$ & $1.81 \mathrm{E}+01$ \\
\hline CAA62024.1 & Mature alpha chain of major histocompatibility complex class I antigen & $2.91 \mathrm{E}-03$ & $1.67 \mathrm{E}+01$ & $1.76 \mathrm{E}+01$ & $1.58 \mathrm{E}+01$ \\
\hline AFD32168.1 & Mitogen-activated protein kinase kinase kinase 1 & $5.26 \mathrm{E}-03$ & $1.51 \mathrm{E}+01$ & $1.66 \mathrm{E}+01$ & $1.50 \mathrm{E}+01$ \\
\hline NP_001101771.1 & Map3k14 & $9.93 \mathrm{E}-04$ & $0.00 \mathrm{E}+00$ & $2.12 \mathrm{E}+01$ & $0.00 \mathrm{E}+00$ \\
\hline AAN86532.1 & Multidrug resistance-associated protein 1 & $2.53 \mathrm{E}-06$ & $1.53 \mathrm{E}+01$ & $1.60 \mathrm{E}+01$ & $1.44 \mathrm{E}+01$ \\
\hline NP_446266.2 & Myosin phosphatase Rho-interacting protein isoform 1 & $1.34 \mathrm{E}-04$ & $1.36 \mathrm{E}+01$ & $1.62 \mathrm{E}+01$ & $1.45 \mathrm{E}+01$ \\
\hline NP_663707.1 & $\mathrm{N}$-acetyllactosaminide alpha-1,3-galactosyltransferase & $5.28 \mathrm{E}-03$ & $1.84 \mathrm{E}+01$ & $1.93 \mathrm{E}+01$ & $1.87 \mathrm{E}+01$ \\
\hline NP_001000033.1 & Olfactory receptor Olr1507 & $4.95 \mathrm{E}-03$ & $1.65 \mathrm{E}+01$ & $1.66 \mathrm{E}+01$ & $1.61 \mathrm{E}+01$ \\
\hline NP_001000682.1 & Olfactory receptor Olr486 & $6.49 \mathrm{E}-04$ & $1.64 \mathrm{E}+01$ & $1.66 \mathrm{E}+01$ & $1.59 \mathrm{E}+01$ \\
\hline NP_001005384.1 & Oncostatin-M-specific receptor subunit beta precursor & $2.38 \mathrm{E}-04$ & $1.76 \mathrm{E}+01$ & $1.92 \mathrm{E}+01$ & $1.61 \mathrm{E}+01$ \\
\hline AAI69002.1 & Phosphatase, orphan 1 & $7.90 \mathrm{E}-03$ & $1.92 \mathrm{E}+01$ & $2.08 \mathrm{E}+01$ & $1.94 \mathrm{E}+01$ \\
\hline NP_114007.1 & Protocadherin Fat 1 precursor & $4.82 \mathrm{E}-04$ & $0.00 \mathrm{E}+00$ & $1.71 \mathrm{E}+01$ & $0.00 \mathrm{E}+00$ \\
\hline NP_536320.1 & Puromycin-sensitive aminopeptidase precursor & $7.38 \mathrm{E}-05$ & $1.56 \mathrm{E}+01$ & $1.71 \mathrm{E}+01$ & $1.60 \mathrm{E}+01$ \\
\hline NP_001008376.1 & Lamtor $^{\ddagger}$ & $3.60 \mathrm{E}-04$ & $1.58 \mathrm{E}+01$ & $1.64 \mathrm{E}+01$ & $1.50 \mathrm{E}+01$ \\
\hline NP_001103357.1 & Receptor-type tyrosine-protein phosphatase $\mathrm{C}$ isoform 3 precursor & $1.62 \mathrm{E}-03$ & $1.72 \mathrm{E}+01$ & $1.94 \mathrm{E}+01$ & $1.65 \mathrm{E}+01$ \\
\hline P38650.1 & Cytoplasmic dynein 1 heavy chain 1 & $6.45 \mathrm{E}-03$ & $1.76 \mathrm{E}+01$ & $1.92 \mathrm{E}+01$ & $1.77 \mathrm{E}+01$ \\
\hline AGG39759.1 & Rh-associated glycoprotein, partial & $1.93 \mathrm{E}-03$ & $1.63 \mathrm{E}+01$ & $1.67 \mathrm{E}+01$ & $1.63 \mathrm{E}+01$ \\
\hline
\end{tabular}


Table 1. Continued

\begin{tabular}{|c|c|c|c|c|c|}
\hline NCBI accession & Identity details & ${ }^{\dagger} \boldsymbol{P}$ & Control & TAA & TAA+AM \\
\hline NP_001161999.1 & Selenocysteine insertion sequence-binding protein 2-like & $7.31 \mathrm{E}-03$ & $1.52 \mathrm{E}+01$ & $1.63 \mathrm{E}+01$ & $1.55 \mathrm{E}+01$ \\
\hline NP_579826.1 & Seminal vesicle antigen-like 1 precursor & $1.50 \mathrm{E}-04$ & $1.96 \mathrm{E}+01$ & $1.99 \mathrm{E}+01$ & $1.87 \mathrm{E}+01$ \\
\hline NP_954526.1 & Seminal vesicle secretory protein 1 precursor & $3.13 \mathrm{E}-04$ & $1.57 \mathrm{E}+01$ & $1.60 \mathrm{E}+01$ & $1.55 \mathrm{E}+01$ \\
\hline AAL77056.1 & SH2 phosphatase 1 & $4.31 \mathrm{E}-03$ & $1.88 \mathrm{E}+01$ & $2.01 \mathrm{E}+01$ & $1.93 \mathrm{E}+01$ \\
\hline NP_001041645.1 & $\mathrm{SH} 2 \mathrm{~B}$ adapter protein 1 isoform 2 & $5.69 \mathrm{E}-04$ & $1.79 \mathrm{E}+01$ & $1.85 \mathrm{E}+01$ & $1.81 \mathrm{E}+01$ \\
\hline EDM04919.1 & Similar to $G$ protein pathway suppressor 2 , isoform CRA_d & $2.32 \mathrm{E}-03$ & $1.60 \mathrm{E}+01$ & $1.81 \mathrm{E}+01$ & $1.61 \mathrm{E}+01$ \\
\hline EDM18475.1 & Similar to RIKEN cDNA 1810020D17, isoform CRA_C & $6.74 \mathrm{E}-03$ & $0.00 \mathrm{E}+00$ & $1.74 \mathrm{E}+01$ & $0.00 \mathrm{E}+00$ \\
\hline NP_113871.1 & Structural maintenance of chromosomes protein $1 \mathrm{~A}$ & $5.12 \mathrm{E}-03$ & $1.76 \mathrm{E}+01$ & $1.84 \mathrm{E}+01$ & $1.73 \mathrm{E}+01$ \\
\hline CAA33552.1 & Sucrase isomaltase, partial & $6.23 \mathrm{E}-03$ & $1.61 \mathrm{E}+01$ & $1.66 \mathrm{E}+01$ & $1.62 \mathrm{E}+01$ \\
\hline CAC37104.1 & TA1 KET beta protein & $7.79 \mathrm{E}-03$ & $1.68 \mathrm{E}+01$ & $1.76 \mathrm{E}+01$ & $1.63 \mathrm{E}+01$ \\
\hline BAH79733.1 & Tensin3 & $1.82 \mathrm{E}-03$ & $1.63 \mathrm{E}+01$ & $1.68 \mathrm{E}+01$ & $1.65 \mathrm{E}+01$ \\
\hline AAI60846.1 & Terf2 protein & $4.22 \mathrm{E}-05$ & $0.00 \mathrm{E}+00$ & $1.78 \mathrm{E}+01$ & $0.00 \mathrm{E}+00$ \\
\hline NP_001258196.1 & Transcription factor SOX-5 & $2.84 \mathrm{E}-04$ & $1.59 \mathrm{E}+01$ & $1.61 \mathrm{E}+01$ & $1.55 \mathrm{E}+01$ \\
\hline NP_620221.2 & Translation initiation factor elF-2B subunit epsilon & 4.87E-05 & $1.42 \mathrm{E}+01$ & $1.45 \mathrm{E}+01$ & $1.36 \mathrm{E}+01$ \\
\hline NP_001102110.2 & Tubulin monoglycylase TTLL3 & $2.82 \mathrm{E}-07$ & $0.00 \mathrm{E}+00$ & $1.68 \mathrm{E}+01$ & $0.00 \mathrm{E}+00$ \\
\hline NP_001100418.1 & Ubiquitin carboxyl-terminal hydrolase 26 & 8.37E-03 & $1.78 \mathrm{E}+01$ & $1.86 \mathrm{E}+01$ & $1.80 \mathrm{E}+01$ \\
\hline NP_598280.1 & UDP-glucose:glycoprotein glucosyltransferase 1 precursor & $8.43 \mathrm{E}-03$ & $1.95 \mathrm{E}+01$ & $2.00 \mathrm{E}+01$ & $1.84 \mathrm{E}+01$ \\
\hline
\end{tabular}

${ }^{\dagger} t$ test.

"Four input proteins were found to be extensively linked to 4 main pathways for fibrosis drawn from the KEGG pathway database upon analysis by STITCH 5.0. Cflar, CASP8 and FADD-like apoptosis regulator; Lamtor3, Ragulator complex protein LAMTOR3; KEGG, Kyoto Encyclopedia of Genes and Genomes; Mapk8ip3, C-Jun-amino-terminal kinase-interacting protein 3; AM, a-mangostin; Map3k14, Mitogen-activated protein kinase kinase kinase 14; NCBI, National Center for Biotechnology Information, U.S. National Library of Medicine; TAA, thioacetamide

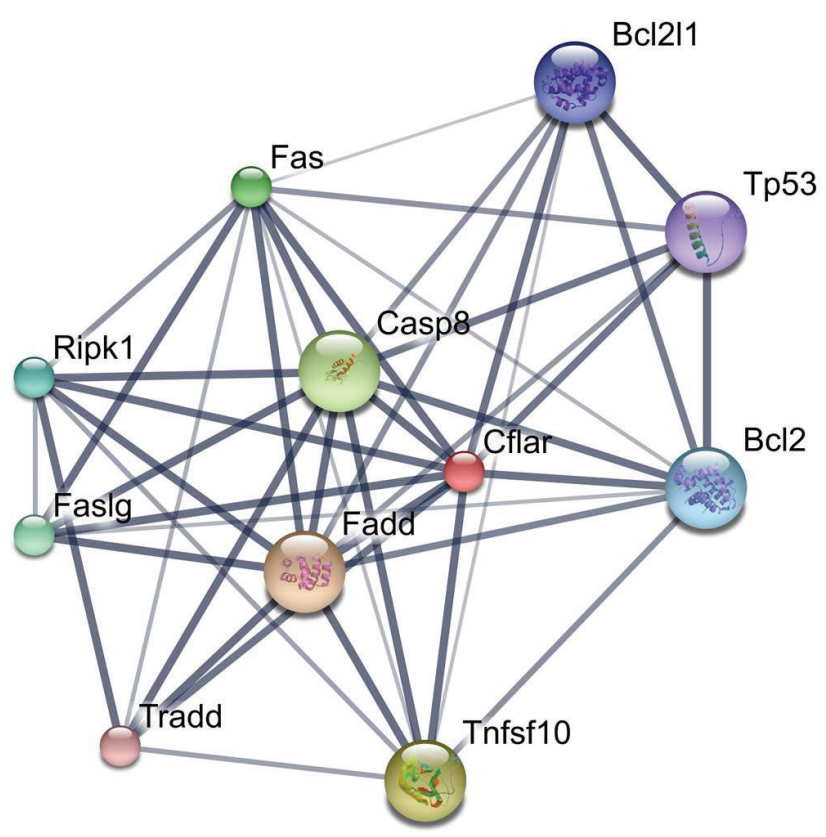

Figure 4. Cflar protein (red node) and its functional partners upon analysis by STITCH 5.0. Analysis of the KEGG identified that Cflar is directly involved pathways corresponding to apoptosis, TNF signaling, NK-KB signaling, and Chagas disease (American trypanosomiasis). Uniprot accession: $\mathrm{COH} 5 Y 5$, Mass: 55,059 Da, Cellular location: Cytosol. Cflar, CASP8 and FADD-like apoptosis regulator; KEGG, Kyoto Encyclopedia of Genes and Genomes; TNF, tumor necrosis factor technique, when used in conjunction with conventional histopathology, provides us with insight into the beneficial effects of AM as a treatment for renal fibrosis.

The histopathology using Sirius Red staining of collagen fibers, a direct measurement of the amount of extracellular matrix, showed that the relative area of collagen fibers was significantly higher in the TAA group than it was in both the control and TAA+AM groups. This is in agreement with studies that have identified the toxic effects of TAA in the kidney manifesting as disruption of the plasma membrane, vesiculation, degranulation of the endoplasmic reticulum, increased number and size of cytosomes, and mitochondrial alterations [22]. These changes are also observed in the more common models of renal fibrosis induced with toxins such as $\mathrm{HgCl}_{2}$ and ethylene glycol [22]. Another study has also found renal dysfunction after TAA exposure; with increased collagen contents, severe tubular epithelial cell death associated with inflammatory cell infiltration, and glomerular congestion also noted [23]. In an animal model induced with TAA, glomeruli displayed congestion because of mesangial cell proliferation and interstitial hemorrhage [24]. Moreover, there was a significant increase in the amount of collagen deposition, as observed using Masson's trichrome and periodic acid Schiff staining [24].

The stained tissue from rats in the TAA + AM group showed a significantly reduced degree of staining when compared with 


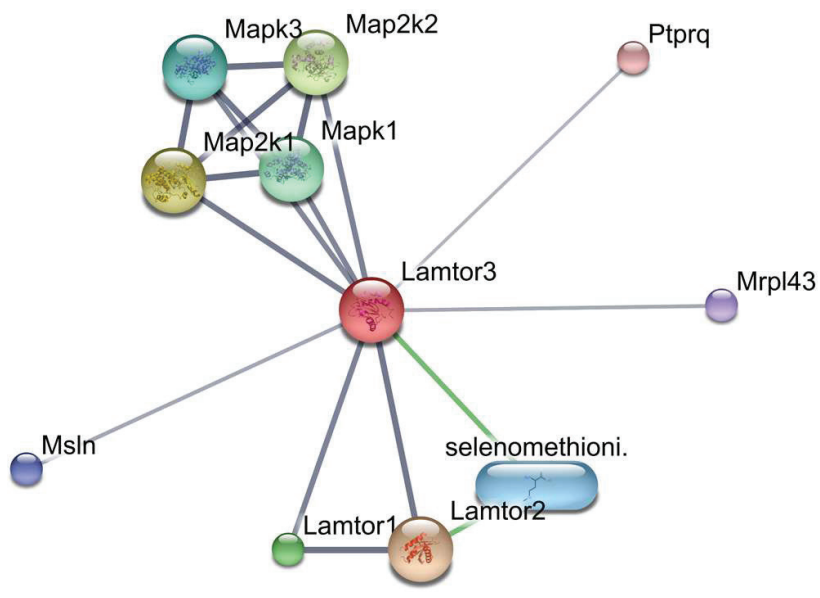

Figure 5. Lamtor3 protein (red node) and its functional partners upon analysis by STITCH 5.0. Analysis of KEGG identified that Lamtor3 is directly involved in the MAPK signaling pathway, but may interface with other pathways including VEGF signaling and tumor formation such as those occurring in thyroid cancer, bladder cancer, endometrial cancer, glioma, non-small cell lung cancer, renal cell carcinoma, and melanoma through its interaction with Mapk1, Map2k1, Mapk3, Map2k2. Uniprot accession: Q5U204, Mass: 13,580 Da, Cellular location: Endosome. Lamtor3, Ragulator complex protein LAMTOR3; KEGG, Kyoto Encyclopedia of Genes and Genomes; VEGF, vascular endothelial growth factor

that in TAA treated rats. Although this is encouraging for AM as a treatment for fibrosis, it was not able to fully reduce the relative fibrotic area to the size seen in the vehicle-treated control rats. This is consistent with a transcriptomic study that concluded a renoprotective effect of AM against cisplatininduced nephrotoxicity at the level of TNF $\alpha$ mRNA, among various other measurements, which were decreased in rats that were treated with AM [25]. The investigators considered that the renoprotective effect of AM is multifactorial, and includes its ability to attenuate free radical-induced damage, inflammatory responses, fibrotic pathways, and preserve catalase activities [25]. In agreement with the belief that AM possesses antioxidant properties are various studies that have shown that AM can serve as free radical scavenger to protect cells from lipid peroxidation; AM was also considered to be able to protect against $\beta$-adrenergic catecholamine induced myocardial toxicity and associated oxidative stress [26]. Attempts to elucidate the molecular mechanisms of AM have also been made, such as an investigation of its ability to induce $\mathrm{Ca}^{2+}$ ATPase-dependent apoptosis via the mitochondrial pathway, and its ability to inhibit the proliferation of colon cancer cells through its regulation of the Wnt/cGMP pathway [27].

Morphological data from Sirius Red staining are often not sufficient to understand the molecular mechanisms that occur in the pathogenesis of renal fibrosis, and so proteomics was chosen to elucidate the mechanisms.

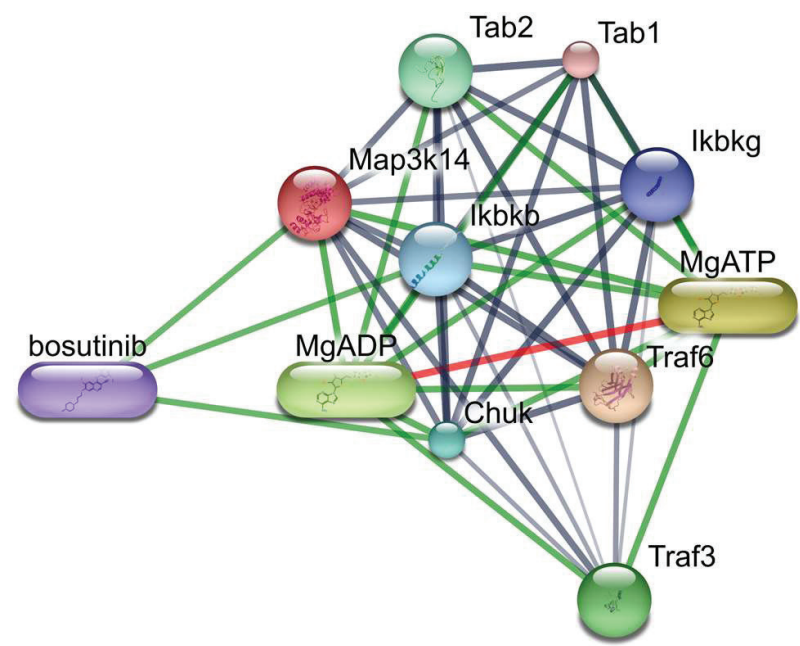

Figure 6. Map3k14 protein (red node) and its functional partners upon analysis by STITCH 5.0. Analysis of KEGG identified that Map3k14 is directly involved in NF-KB signaling, Epstein-Barr virus infection, TNF signaling, and MAPK signaling, and apoptosis. Uniprot accession: D3ZTD1, Mass: 103,584 Da, Cellular location: Cytosol and Nucleus. KEGG, Kyoto Encyclopedia of Genes and Genomes; Map3k14, Mitogen-activated protein kinase kinase kinase $14 ; \mathrm{TNF}$, tumor necrosis factor

Upon STITCH 5.0 analysis of the 68 proteins that had trends of expression associated with the relative Sirius Red collagen staining of kidneys, 4 proteins were considered to be involved in pathways that are implicated in the pathogenesis of fibrosis and related conditions.

Cflar, or cellular FADD-like IL-1 $\beta$-converting enzyme (FLICE)-inhibitory protein (c-FLIP), an antiapoptotic regulator, is upregulated in various types of cancer including colorectal cancer, bladder urothelial cancer, cervical cancer, Burkitt's lymphoma, non-Hodgkin's lymphoma, head and neck squamous cell carcinoma, and hepatocellular carcinoma [28]. Pancreatic ductal adenocarcinomas also showed increased levels of c-FLIP despite its absence in normal pancreatic ducts [29]. This increase is because c-FLIP inhibits the extrinsic, or death receptor-mediated, apoptotic pathway [28]. In the extrinsic pathway of apoptosis, c-FLIP inhibits the activation of caspase- 8 and caspase- 10 by competitively binding to FADD that is vital for the recruitment of procaspase- 8 and procaspase-10 before their activation and apoptotic activities [30]. However, the increase in c-FLIP expression seems to contradict the pathogenesis of fibrosis because increased apoptosis initiates fibrosis. A possible explanation is that, at the transcriptional level, c-FLIP is activated by various stimuli from the immune response implicated in the pathogenesis of fibrosis such as TNF ligands, interleukins, and chemokines [30]. Map3k14, involved in the TNF signaling pathway, was upregulated in renal tissue from rats in the TAA group and downregulated in renal tissue from rats in the TAA + AM 


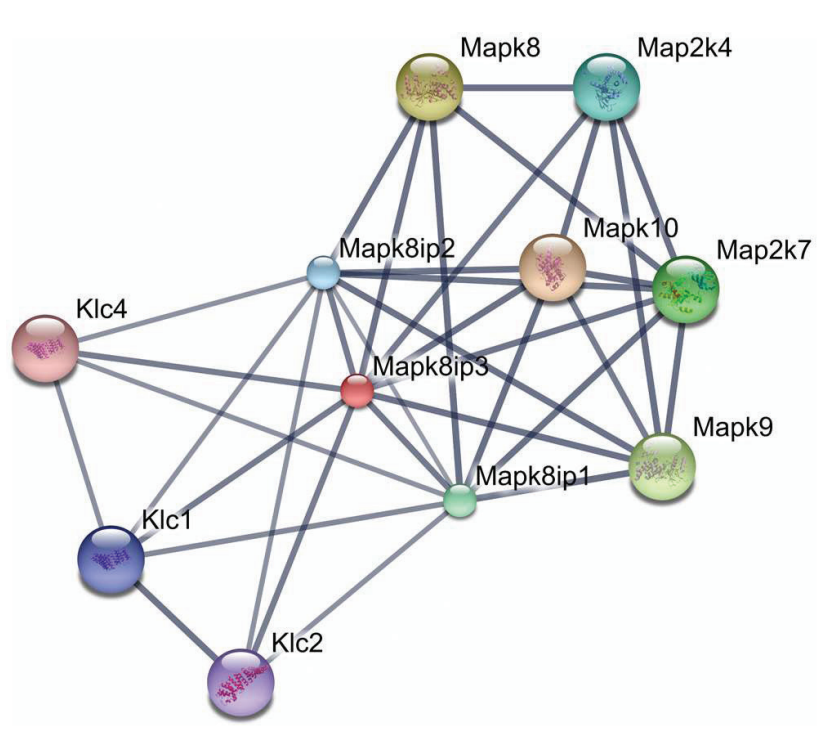

Figure 7. Mapk8ip3 protein (red node) and its functional partners upon analysis by STITCH 5.0. Analysis of KEGG identified that Mapk8ip3 is directly involved in the MAPK signaling pathway. Mapk8ip3 may interface with activities that involve the JNK cascade because of its interaction with Mapk8, Mapk10, and Mapk9, which play important roles in apoptosis, inflammation, cytokine production, and metabolism activated in response to environmental stress. Uniprot accession: BOVXR4, Mass: 145,619 Da, Cellular location: Endoplasmic reticulum and Golgi apparatus. KEGG, Kyoto Encyclopedia of Genes and Genomes; JNK, C-Jun N-terminal kinase; Mapk8ip3, C-Jun-amino-terminal kinaseinteracting protein 3

group. CX3C chemokine receptor 1 and the $\mathrm{C}-\mathrm{X}-\mathrm{C}$ motif chemokine 14, which are involved in chemokine signaling are also present among the 68 proteins identified by the analysis. Interestingly, tumor protein 63 (shown as TA1 KET beta protein in Table 1), a transcription factor that directly activates the transcription of c-FLIP, is one of the 68 proteins that followed the trend in the relative Sirius Red collagen staining [31]. $\mathrm{NF}-\kappa \mathrm{B}$ induces c-FLIP [30].

Lamtor3, also known as MP1 (mitogen-activated protein kinase [MAPK]/extracellular signal-regulated kinase [ERK] kinase or MEK partner 1) or MAPK, and mechanistic target of rapamycin (mTOR) activator 3 are scaffold proteins that serve as docking platforms that bind specifically to MEK1 and ERK1 to facilitate their interactions through specific protein-protein interactions and enhance the efficiency of the MAP kinase cascade [32]. Hyperactivation of MEK and ERK through enhanced transcriptional activation of Lamtor3 can lead to pancreatic cancer cell proliferation [33]. MAP kinases can also promote a fibrotic response through a number of different mechanisms including the production and activation of TGF- $\beta 1$, regulating TGF- $\beta 1-$ Smad signaling, and TGF- $\beta 1$-independent profibrotic actions, which are implicated epithelial-mesenchymal transition - a process vital to the pathogenesis of fibrosis [34]. Therefore, a rise in the level of Lamtor3 could lead to an increased level of TGF- $\beta 1$, which is the central node of the pathogenesis of fibrosis.

Map3k14, also known as NF- $\mathrm{B}$-inducing kinase (NIK), is involved in noncanonical NF- $\kappa \mathrm{B}$ signaling. This pathway is involved in the production of inflammatory chemokines such as CCL19 and CCL21, which are responsible for the recruitment of T-cells and fibrocytes to the kidney [35]. NF- $\kappa B$ is deeply involved in mediating inflammatory responses and the pathogenesis of renal inflammatory diseases. For example, $\mathrm{NF}-\kappa \mathrm{B}$ levels are elevated in folic acid and ischemic reperfusion-induced acute kidney injury [36]. In its usual inactive state, NF- $\kappa B$ binds to the I $\kappa \mathrm{B} \alpha$ inhibitory subunit and dissociation must occur before NF- $\kappa \mathrm{B}$ can translocate into the nucleus from the cytoplasm to exert its biological effects through transcriptional activation [36]. This is achieved by the actions of IкB kinase (IKK $\alpha$ ) and NIK. Upon appropriate ligand receptor binding, NIK is activated and phosphorylates IKK $\alpha$, which leads to ubiquitination and degradation of $\mathrm{I} \kappa \mathrm{B} \alpha$, resulting in the activation of NF- $\mathrm{KB}$ [37]. In healthy cells, the level of NIK is kept low to undetectable because of it is constantly degraded when no stimuli are present [36]. TNF stimulation can prevent the degradation of NIK [38]. In the present study, we found that the level of NIK is relatively high and only present in renal tissue from TAA-treated rats.

Mapk8ip3, also known as C-Jun N-terminal kinase (JNK)/ stress-activated protein kinase-associated protein 1 (JSAP1) and JNK-interacting protein 3 (JIP3), is a scaffold protein that is important in mediating and enhancing the signaling of protein kinase components of JNK modules in response to harmful extracellular stimuli such as inflammatory cytokines, ultraviolet irradiation, and oxidative stress. [39]. Activation of the JNK pathway results in a wide variety of cellular responses such as tubular epithelial cell production of proinflammatory and profibrotic molecules as well as tubular cell dedifferentiation toward a mesenchymal phenotype [39, 40]. JIP3 has also been shown to interact with Raf-1 and MEK1 in the ERK signaling module, the latter being scaffolded by the aforementioned MP1 [41]. Furthermore, JSAP1/JIP3 serve as cooperative scaffolds for activation of focal adhesion kinase (FAK), which has been implicated in the pathogenesis of fibrosis [42]. Fibrotic cells display persistent FAK activation and enhanced adhesion capacity and migration [43].

This study is limited because research into the pathogenesis of fibrosis is still emerging and there is still much to be discovered, the proteins described above might not act as suggested, but operate through different, as yet unknown, pathways. The molecular pathways leading to the onset of fibrosis remain incompletely elucidated and ambiguous. 


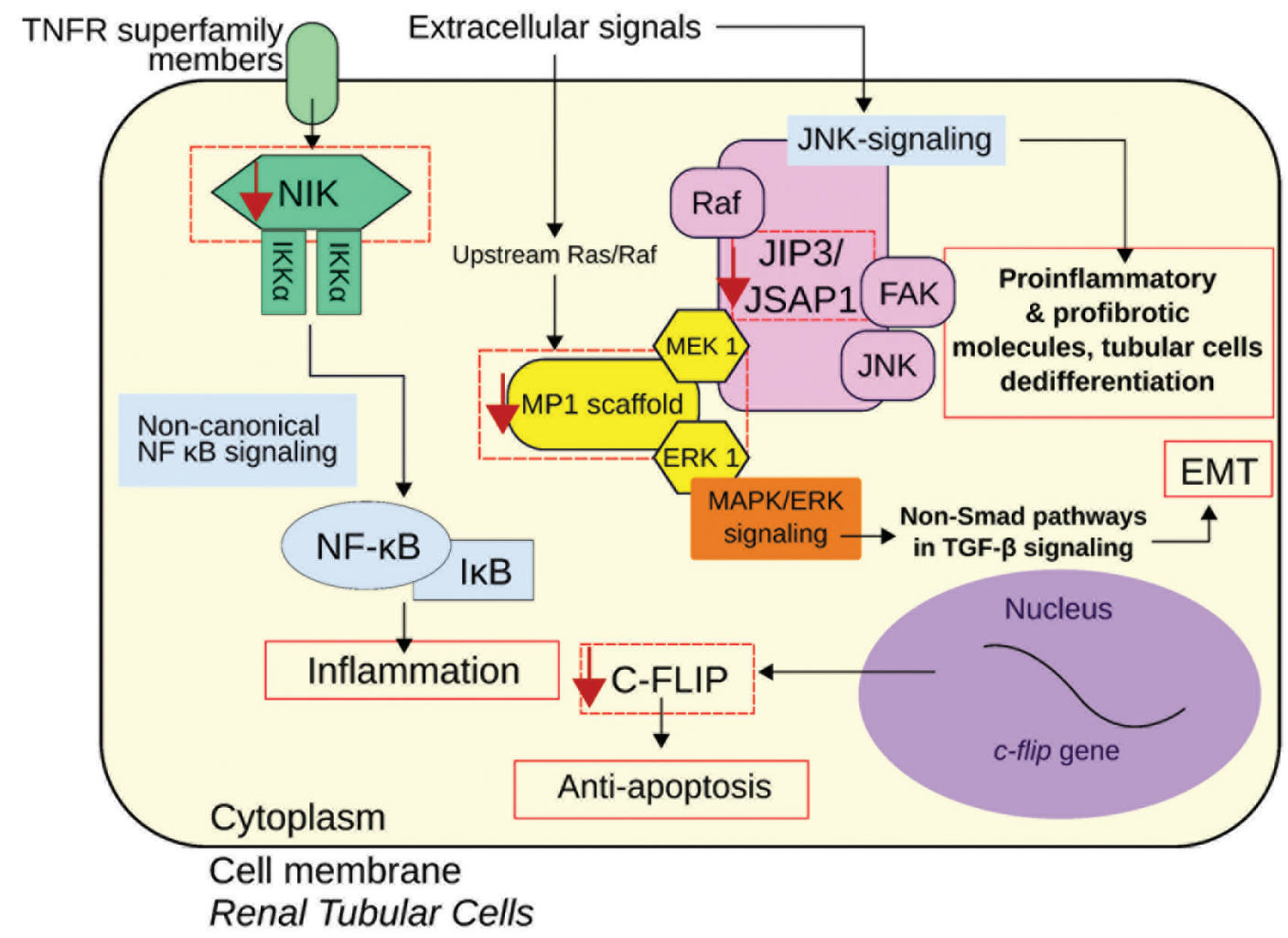

Figure 8. Summarized hypothesized activities of $A M$ and its related pathways. AM, a-mangostin; EMT, epithelial-mesenchymal transition; ERK, extracellular signal-regulated kinase; FAK, focal adhesion kinase; c-FLIP, Cflar also known as cellular FADD-like IL-1 $\beta$-converting enzyme (FLICE)-inhibitory protein; IkB, inhibitors of NF-KB; IKKa, JNK, Mapk8ip3 also known as C-Jun N-terminal kinase; JIP3, JNK-interacting protein 3; JSAP, JNK-stress-activated protein kinase-associated protein 1; MAPK, mitogen-activated protein kinase; MEK, MAPK/ERK kinase; MP1, Lamtor3 also known as MEK partner 1; NF-KB, nuclear factor K-light-chain-enhancer of activated B cells; NIK, Map3k14 also known as NF-KB-inducing kinase; Raf, Rapidly accelerated fibrosarcoma proto-oncogene serine/threonine-protein kinase; Ras, rat sarcoma small GTPase; TGF- $\beta$, transforming growth factor- $\beta$; TNFR, Tumor necrosis factor receptor

\section{Conclusions}

In an attempt associate our various findings, we hypothesize that AM exhibits a wide range of effects against fibrosis such as attenuating upstream activators of c-FLIP transcription, such as TNF ligands, interleukins, chemokines, or tumor protein 63, and reducing levels of Lamtor3 to prevent facilitating the MAP kinase signaling involved in fibrotic diseases. Furthermore, AM may attenuate upstream inflammatory responses leading to an overall reduction of noncanonical NF- $\kappa \mathrm{B}$ signaling, as suggested by the markedly reduced level of Map3k14 found in the present study. We also propose that AM may reduce signaling by attenuating harmful stimuli that activate the JNK pathway. AM treatment may result in slight alterations in many pathways as shown in the reduction in signal intensities of key actors in the aforementioned pathways leading to an improvement of the overall fibrotic condition as supported by the histology (Figure 8). This is congruent with the pathogenesis of fibrosis, which like many other complex conditions, is caused by a disturbance in not just one biological pathway, but rather as a manifestation of many small disturbances leading to the observed pathogenesis.

Author contributions. SR and WP contributed substantially to the conception and design of this study. TC, VT, and NP contributed substantially to the acquisition of data. TC, SR, US, and WP analyzed and interpreted data. All the authors drafted and critically revised the manuscript, approved the final version submitted, and take responsibility for statements made in the published article.

Acknowledgments. The authors express their gratitude to the staff of the Laboratory Animal Center of Faculty of Medicine, Srinakharinwirot University, for their care of the rats and the staff, especially Ms. Jantima Jaresitthikunchai, of the Proteomics Research Laboratory, Genome Institute, National Center for Genetic Engineering and Biotechnology, Thailand, for their help 
with the proteomics. This study was supported by grants from the Faculty of Medicine, Srinakharinwirot University, Thailand, 2015 (No. 219/2558). The present work was presented in part as a poster at the 41st Annual Conference of the Anatomy Association of Thailand (AAT41), 2018 May 23-25, Cha-am, Phetchaburi, Thailand. Sureeporn Nak-ung, Nutnicha Nakprom, Chonikan Maneegam, Sutisa Nudmamud-Thanoi, Samur Thanoi. Proteomics study on the effects of alpha-mangostin against renal fibrosis in rats [PP 25, AAT158].

Conflict of interest statement. The authors have each completed and submitted an International Committee of Medical Journal Editors Uniform Disclosure Form for Potential Conflicts of Interest. None of the authors has any potential conflict of interest to disclose.

\section{References}

[1] Neild GH. Life expectancy with chronic kidney disease: an educational review. Pediatr Nephrol. 2017; 32:243-8.

[2] Turin TC, Tonelli M, Manns BJ, Ravani P, Ahmed SB, Hemmelgarn BR. Chronic kidney disease and life expectancy. Nephrol Dial Transplant. 2012; 27:3182-6.

[3] Liu Y. Epithelial to mesenchymal transition in renal fibrogenesis: pathologic significance, molecular mechanism, and therapeutic intervention. Clin J Am Soc Nephrol. 2004; 15:1-12.

[4] Singh NP, Ganguli A, Prakash A. Drug-induced kidney diseases. J Assoc Physicians India. 2003; 51:970-9.

[5] Taal M, Brenner B. Predicting initiation and progression of chronic kidney disease: developing renal risk scores. Kidney Int. 2006; 70:1694-705.

[6] Collins AJ, Foley RN, Gilbertson DT, Chen S-C. United States Renal Data System public health surveillance of chronic kidney disease and end-stage renal disease. Kidney Int Suppl. 2015; $5: 2-7$.

[7] Klinkhammer BM, Goldschmeding R, Floege J, Boor P. Treatment of renal fibrosis-turning challenges into opportunities. Adv Chronic Kidney Dis. 2017; 24:117-29.

[8] El Nahas A, Muchaneta-Kubara E, Essaway M, Soylemezoglu O. Renal fibrosis: insights into pathogenesis and treatment. Int J Biochem Cell Biol. 1997; 29:55-62.

[9] Ibrahim MY, Hashim NM, Mariod AA, Mohan S, Mahmood AA, Arbab IA. a-Mangostin from Garcinia mangostana Linn: an updated review of its pharmacological properties. Arab J Chem. 2016; 9:317-29.

[10] Govindachari T, Kalyanaraman P, Muthukumaraswamy N, Pai B. Xanthones of Garcinia mangostana Linn. Tetrahedron. 1971; 27:3919-26.

[11] Poonkhum R, Watanapokasin R, Pradidarcheep W. Protective effect of alpha-mangostin against type-I collagen formation in thioacetamide-induced cirrhotic rat. J Med Assoc Thai. 2012; 95:S93-8.

[12] Martínez-Abundis E, García N, Correa F, Hernández-Reséndiz S, Pedraza-Chaverri J, Zazueta C. Effects of a-mangostin on mitochondrial energetic metabolism. Mitochondrion. 2010; 10:151-7.
[13] Mas VR, Fisher RA, Archer KJ, Maluf DG. Proteomics and liver fibrosis: identifying markers of fibrogenesis. Expert Rev Proteomics. 2009; 6:421-31.

[14] Moongkarndi P, Jaisupa N, Samer J, Kosem N, Konlata J, Rodpai E, Pongpan N. Comparison of the biological activity of two different isolates from mangosteen. J Pharm Pharmacol. 2014; 66:1171-79.

[15] Junqueira LCU, Bignolas G, Brentani R. Picrosirius staining plus polarization microscopy, a specific method for collagen detection in tissue sections. Histochem J. 1979; 11:447-55.

[16] Schneider CA, Rasband WS, Eliceiri KW. NIH Image to Image): 25 years of image analysis. Nat Methods. 2012; 9:671-5.

[17] Lowry OH, Rosebrough NJ, Farr AL, Randall RJ. Protein measurement with the Folin phenol reagent. J Biol Chem. 1951; 193:265-75.

[18] Blum H, Beier H, Gross HJ. Improved silver staining of plant proteins, RNA and DNA in polyacrylamide gels. Electrophoresis. 1987; 8:93-9.

[19] Jaresitthikunchai J, Phaonakrop N, Kittisenachai S, Roytrakul S. Rapid in-gel digestion protocol for protein identification by peptide mass fingerprint. Proceedings of the 2nd Biochemistry and Molecular Biology Conference: Biochemistry and Molecular Biology for Regional Sustainable Development. 2009 May 7-8, Khon Kaen, Thailand. p. 29.

[20] Johansson C, Samskog J, Sundström L, Wadensten H, Björkesten L, Flensburg J. Differential expression analysis of Escherichia coli proteins using a novel software for relative quantitation of LC - MS/ MS data. Proteomics. 2006; 6:4475-85.

[21] Szklarczyk D, Franceschini A, Kuhn M, Simonovic M, Roth A, Minguez P, et al. The STRING database in 2011: functional interaction networks of proteins, globally integrated and scored. Nucleic Acids Res. 2011; 39(Database issue):D561-8.

[22] Barker EA, Smuckler EA. Nonhepatic thioacetamide injury: II. The morphologic features of proximal renal tubular injury. Am J Pathol. 1974; 74:575.

[23] Ghosh S, Sarkar A, Bhattacharyya S, Sil PC. Silymarin protects mouse liver and kidney from thioacetamide induced toxicity by scavenging reactive oxygen species and activating PI3K-Akt pathway. Front Pharmacol. 2016; 7:481. doi: 10.3389/ fphar.2016.00481.

[24] Adler SG, Schwartz S, Williams ME, Arauz-Pacheco C, Bolton WK, Lee T, et al. Phase 1 study of anti-CTGF monoclonal antibody in patients with diabetes and microalbuminuria. Clin J Am Soc Nephrol. 2010; 5:1420-8.

[25] Pérez-Rojas JM, Cruz C, García-López P, Sánchez-González DJ, Martínez-Martínez CM, Ceballos G, et al. Renoprotection by $\alpha$-mangostin is related to the attenuation in renal oxidative/ nitrosative stress induced by cisplatin nephrotoxicity. Free Radic Res. 2009; 43:1122-32.

[26] Devi Sampath P, Vijayaraghavan K. Cardioprotective effect of $\alpha$-mangostin, a xanthone derivative from mangosteen on tissue defense system against isoproterenol-induced myocardial infarction in rats. J Biochem Mol Toxicol. 2007; 21:336-9.

[27] Sato A, Fujiwara H, Oku H, Ishiguro K, Ohizumi Y. a-Mangostin induces $\mathrm{Ca}^{2+}$-ATPase-dependent apoptosis via mitochondrial pathway in PC12 cells. Am J Pharmacol Sci. 2004; 95:33-40.

[28] Safa A. c-FLIP, a master anti-apoptotic regulator. Exp Oncol. 2012; 34:176-84

[29] Haag C, Stadel D, Zhou S, Bachem MG, Möller P, Debatin KM, Fulda S. Identification of $\mathrm{c}-\mathrm{FLIP}_{\mathrm{L}}$ and c-FLIP $\mathrm{S}$ as critical regulators 


\section{IIlli, ASIAN BIOMEDICINE}

of death receptor-induced apoptosis in pancreatic cancer cells. Gut. 2011; 60:225-37.

[30] Safa AR, Day TW, Wu C-H. Cellular FLICE-like inhibitory protein (C-FLIP): a novel target for cancer therapy. Curr Cancer Drug Targets. 2008; 8:37-46.

[31] Borrelli S, Candi E, Alotto D, Castagnoli C, Melino G, Viganò MA, Mantovani R. p63 regulates the caspase-8-FLIP apoptotic pathway in epidermis. Cell Death Differ. 2009; 16:253-63.

[32] Schaeffer HJ, Catling AD, Eblen ST, Collier LS, Krauss A, Weber MJ. MP1: a MEK binding partner that enhances enzymatic activation of the MAP kinase cascade. Science. 1998; 281(5383):1668-71.

[33] Jun S, Lee S, Kim H-C, Ng C, Schneider AM, Ji H, et al. PAF-mediated MAPK signaling hyperactivation via LAMTOR3 induces pancreatic tumorigenesis. Cell Rep. 2013; 5:314-22.

[34] Ma FY, Sachchithananthan M, Flanc RS, Nikolic-Paterson DJ. Mitogen activated protein kinases in renal fibrosis. Front Biosci (Schol Ed). 2009; 1:171-87.

[35] Banas B, Wörnle M, Berger T, Nelson PJ, Cohen CD, Kretzler M, et al. Roles of SLC/CCL21 and CCR7 in human kidney for mesangial proliferation, migration, apoptosis, and tissue homeostasis. J Immunol. 2002; 168:4301-7.

[36] Zhang H, Sun S-C. NF- $\kappa B$ in inflammation and renal diseases. Cell Biosci. 2015; 5:63. doi: 10.1186/s13578-015-0056-4
[37] Zhang X, Wang Y, Mao Z, Huang D, Zhou J, Wang X. Expression of NF-kB-inducing kinase in breast carcinoma tissue and its clinical significance. Int J Clin Exp Pathol. 2015; 8:14824-9.

[38] Choudhary S, Kalita M, Fang L, Patel KV, Tian B, Zhao Y, et al. Inducible tumor necrosis factor (TNF) receptor-associated factor-1 expression couples the canonical to the non-canonical NF- $\mathrm{kB}$ pathway in TNF stimulation. J Biol Chem. 2013; 288: 14612-23.

[39] Ito M, Yoshioka K, Akechi M, Yamashita S, Takamatsu N, Sugiyama K, et al. JSAP1, a novel jun $\mathrm{N}$-terminal protein kinase (JNK)-binding protein that functions as a Scaffold factor in the JNK signaling pathway. Mol Cell Biol. 1999; 19:7539-48.

[40] Grynberg K, Ma FY, Nikolic-Paterson DJ. The JNK signaling pathway in renal fibrosis. Front Physiol. 2017; 8:829. doi: 10.3389/ fphys.2017.00829

[41] Dhanasekaran D, Kashef K, Lee C, Xu H, Reddy E. Scaffold proteins of MAP-kinase modules. Oncogene. 2007; 26:3185-202.

[42] Takino T, Nakada M, Miyamori H, Watanabe Y, Sato T, Gantulga D, et al. JSAP1/JIP3 cooperates with focal adhesion kinase to regulate c-Jun N-terminal kinase and cell migration. J Biol Chem. 2005; 280:37772-81.

[43] Lagares D, Kapoor M. Targeting focal adhesion kinase in fibrotic diseases. BioDrugs. 2013; 27:15-23. 